\title{
Matrisit ve Suisidal Düşünceleri Olan Ergen: Olgu Sunumu
}

\section{Adolescent with Matricidal and Suicidal Thoughts: A Case Report}

\author{
Berna Polat, Veli Yildırm, Fevziye Toros
}

Mersin Üniversitesi Tıp Fakültesi Çocuk ve Ergen Ruh Sağllğı ve Hastalıklarn AD, Mersin

\section{Özet}

Matrisit; annenin, oğlu ya da kızı tarafından cinayeti olarak tanımlanabilir. Literatürde nadir görülen ve az bilgiye sahip olunan matrisit gibi homisidal davranışları etkileyen sosyolojik, biyolojik, psikolojik ve çevresel etkenlerle olan ilişkilerin araştırıldığı çalışmalar nadiren görülmektedir. Bu olgu da nadir görülen bir durumun literatüre katkıda bulunması amacıyla sunulmuștur.

Anahtar kelimeler: Ergen, Matrisit, Homisidal davranışlar.

\begin{abstract}
Matricide can be defined as the murder of mother by her son or daughter. The study conducted to investigate the relationship among biological, physiological and environmental affect on behavioural homicide such as matricide are seem rarely in literature and it is also hard defined acquired information about this issue. This case report was presented to contribute the literature about this kind of situation.
\end{abstract}

Keywords: Adolescent, Matricide, Homicidal behaviours.

\section{Giriş}

Matrisit; annenin, oğlu ya da kızı tarafından cinayeti olarak tanımlanabilir. Parrisit; kişinin, annesini, babasını veya yakın akrabalarını öldürmesidir. Matrisit terimi yerine parrisit de kullanılabilmektedir (1). Ergenlerde nadir görülen ve hakkında az bilgiye sahip cinayetle sonuçlanan homisidal davranışlar incelendiğinde; literatürde olgu sunumları ve olgu serilerinin yer aldığı bazı çalışmalar görülmektedir $(2,3)$. Matrisit ise tüm cinayetlerin içinde \%1'den daha az bir oranda görülmektedir (4). Bu olgu; literatüre katkıda bulunmak ve olgudaki matrisit olayını tartışmak amacıyla sunulmuştur.

\section{Olgu Sunumu}

16 yaşında erkek, suisid düşünceleri nedeniyle cezaevi görevlileri tarafından polikliniğimize getirildi. Annesine karşı yapmış olduğu saldırgan davranışı nedeniyle cezaevinde kaldığı ögrenildi.

İki kardeşten birincisi olan olgunun, ortaokulu bitirdiği, annesinin ilkokul mezunu ve ev kadını olduğu, babasının ilkokul mezunu olduğu ve serbest çalıştığı ögrenildi. Öz geçmişinde beş yıldır sigara kullanımı; iki yıldır, iki üç günde bir alkol ve madde kullanımı olduğunu belirtti. Soy geçmişinde ise babada alkol bağımlılığı öyküsü vardı.

Son bir yıldır kendine zarar verici davranışlarının artığı öğrenildi. Vücudunda ve kollarında jilet ve sigara izleri ile dövmeler mevcuttu. Önceden bir kez intihar girissimi olduğu, birçok kez de hırsızlık ve kavgadan dolayı adli süreçlerde değerlendirildiği öğrenildi. Akademik başarısının ilkokulda sınıf düzeyinde, ortaokulda sınıfın gerisinde olduğunu belirtti. Liseyi de ilk yılında okumak istemediği ve derslerinin iyi olmadığı gerekçesiyle bırakmıştı. Aile içindeki bireyler arasında, uzun süredir sözel ve fiziksel şiddet olduğu ifade edildi.

Olgu; yaklaşık üç ay önce kız kardeşini hırsızlık yapması için zorladığı gerekçesiyle annesiyle tartışmaya girdiğini anlattı. Daha sonra madde kullanımının etkisi ve anlık öfkeyle, evde bulunan av tüfeği ile annesini başından yaraladığını, annesinin yoğun bakımda bir ay kadar yattığını ve sonrasında da öldüğünü aktardı. Annesinin ölümünden sonra ruhsal sıkıntılarının arttığı öğrenildi. Olgu cezaevinin bulunduğu ilçedeki hastanede psikolog ve psikiyatrist tarafından yaklaşık bir aydır takip edildiğini, ancak kendisine verilen ilaçları içmek istemediğini söyledi. İlaç tedavisine uyum sağlamaması ve suisid düşünceleri nedeniyle polikliniğimize gönderilmişti.

Giyimi sosyoekonomik düzeyine uygun, özbakımı azalmış, yaşını gösteren ergen olgunun, duygudurumu ve duygulanımı depresif ve disforikti. Düşünce içeriğinde suisidal düşünceler, annesi ile ilgili yoğun suçluluk temalı düşünceleri mevcuttu. Konuşmasında yaşına ve eğitim düzeyine göre kısıtlı sözcük kullanımı vardı. Dikkati dağınıktı. Uykuları bozuk, iştahı azalmıştı. Yaşanan olayla ilgili içgörüsü kısmen mevcuttu.

Olguda psikotik özellikli Major Depresif Bozukluk, Travma Sonrası Stres Bozukluğu, Dikkat Eksikliği ve Hiperaktivite Bozukluğu (DEHB), Davranım Bozukluğu, Madde Kullanım Bozukluğu, antisosyal kişilik özellikleri ile kaotik aile yapısı; duygusal ihmal, yoğun fiziksel istismar olduğu düşünüldü. 
$\mathrm{Bu}$ olay sonrasında olgunun; aşırı suçluluk duyguları, suisid düşünceleri ve planları, işitsel ve görsel sanrıları, olayla ilgili flashback'leri, uykuya dalamama, ssk sık uyanma, kabus görmeleri, iştahsızlı̆̆ı, ağır depresif duygudurumu olması nedeniyle yataklı bir kurumda tedavi edilmesi gerektiği düşünülerek sevki yapıldı.

\section{Tartişma}

Matrisit; annenin biyolojik çocuğu tarafından öldürülmesidir. Amerika'da tüm homisid olgularının içinde matrisit \%2'den daha az görülmekte; daha çok erkek çocukları tarafından, geç ergenlik döneminde gerçekleşmektedir (5).

Bir çalışmada matrisit olguları incelenmiş; cinayet öncesi öykülerinde bu olguların \%90'ında emosyonel veya fiziksel istismarın olduğu, ruhsal bir bozukluğun (en sik travma sonrası stres bozukluğu) eşlik ettiği fakat antisosyal kişilik özelliklerinin çok az olduğu gösterilmiştir. Tüm olguların ebeveynlerinin evinde yaşadığı, en sık ateşli silah kullandıkları ve bu silahların evlerinde mevcut olduğu belirtilmiștir (6).

Cinayet suçu işleyen gençleri etkileyen çevresel faktörlere bakıldığında; ebeveyn istismarı, aile içi şiddet, eş kötüye kullanımı, duygusal istismar ve anne babalar arasında ağır alkol tüketimi, ebeveyn terki ve yoksulluğun son derece yaygın olduğu tespit edilmiştir (7). Aile üyeleri arasında ateşli silah ile ilişkili cinayetlerde, suçluların ve kurbanlarının yaklaşı \%90'1 cinayetler öncesi alkol ya da uyuşturucu kullanmaktadır (1). Yine homisidal ergenlerde yapılan bir çalışmada; homisid öncesi daha yüksek agresif davranışlar gösterdikleri tespit edilmiştir (karşıt olma karşıt gelme bozukluğu DEHB, davranım bozukluğu) (8).

Çalışmalar cinayet davranışı ile psikiyatrik bozukluklar (madde kullanımı bozuklukları, istismar gibi) arasında bir ilişki olduğunu göstermektedir (9). Sağlık, ekonomik ve duygusal ihmal ve istismarın sık olduğu, alkol madde kullanımı olan ailelerde ebeveyn ergen arasındaki ilişki sorunlarının daha şiddetli olduğu ancak tedavi ve destek amaçlı direk psikiyatri başvurusunun daha az olduğu bilinmektedir $(10,11,12)$. Olgumuzda da öncesinde psikiyatri başvurusu olmamakla birlikte ihmal ve istismar öyküsünün olduğu, babasının alkol madde kullanım bozukluğu, kendisinin madde kullanım öyküsü olduğu ve olgunun düşük bilişsel kapasitede olduğu belirlenmiştir. Ailenin soy geçmişi ile ilgili ayrıntılı bilgi sahibi olmamakla birlikte düşük sosyoekonomik düzeyde oldukları, psikiyatrik bozukluklara sahip oldukları öngörülmektedir.

Aile içi şiddetle karşılaşmış, parçalanmış aile yapısı olan, yüksek agresivite içeren davranışlar sergileyen, mevcut psikiyatrik bozukluk öyküsü bulunan aile üyelerinde "öldürme ardından özkıyım girişim riski” oldukça yüksek olarak belirtilmiştir (13).

Retrospektif çalışılmış yedi parrisit olgusunda; mağdurların ve suç işleyenlerin çoğunluğunun erkek olduğu, aynı evde yaşadıkları ve çoğunlukla suçun evde işlendiği, başlıca iddia edilen suça götüren sebepler olarak da tedavisiz psikiyatrik bozukluklar, aile içi şiddet ve ekonomik çatışmalar olduğu gösterilmiştir (14). Ayrıca Kanada'da 12-17 yaş aralığında homisidal gençlerde; mağdurla ilişkisi araştırılmış, mağdurların en çok yabancı olduğu, cinayet aleti olarak en sık bıçak kullandığı, en az ise ateşli silah kullanımı olduğu gösterilmiştir. Bizim olgumuzda da ateşli silah kullanımı mevcuttu (15).

Matrisit olgularını literatürde incelendiğimizde; bu olguların cinayet öncesi ve sonrasındaki sosyolojik, biyolojik, psikolojik ve çevresel etkenlerle olan ilişkileri araştırılmış fakat çoğunlukla kısıtlı olgu serileri ile sınırlı kalınmıştır.

Bizim olgumuzda da olduğu gibi ciddi homisidal davranıșları olan çocuk ve ergenlerde koruyucu tedbirler alınması gerekmektedir. DEHB ve davranım bozukluğu olan çocuklara adli süreçlerde, özellikle ailenin kaotik yapıda olduğu ve çocukta iç görünün az olduğu durumlarda sağlık tedbiriile ilaç tedavisi mutlaka sağlanmalıdır.

Ebeveynlerine yönelik agresivitesi olan ergenler; aile ile birlikte psikoterapiye alınmalı, aile içi ilişkileri düzeltme ve iletişimi artırma ve problem çözme becerilerini geliştirmelerine yardımcı olunmalıdır. Aile üyelerinin ve ergenin mevcut ruhsal bozukluklarının tedavisi yapılmal, gerektiğinde hastaneye yatırılarak tedavi edilebilme imkanı sağlanmalı ve farmakolojik tedavisi düzenlenmelidir. Bazı durumlarda da yaşanılan sosyal çevrenin değiştirilmesi gerekebilmektedir. Eğitim kurumlarının gençlerle ilgili yaşanılan problemlerde daha fazla destek almaları sağlanarak gençlerin okula uyumunun arttırılması ve akran ilişkilerinin düzenlenmesi önemli koruyucu rol oynayacaktır (16).

Bunun yanında kaotik yapılardaki ailelerde eğitim, danışmanlık, bakım ve barınma tedbir kararlarının gözden geçirilerek hızlı bir şekilde uygulanması; hem öğretmenlerin, hem sağlık çalışanlarının sorumluluğu olmalıdır.

Ayrıca çocuklarda da madde kullanımı durumunda sağlık tedbir kararının alınması olguların gidişatı açısından büyük önem taşımaktadır.

Sonuç olarak; ölümle sonuçlanan olguların özelliklerinin ayrıntılı incelenmesinin ileride benzer olguların olmasını önlenmesine faydası olacaktır. Bu konuda önleyici tedbirlerin belirlenebilmesi için daha fazla çalışmanın yapılmasına ihtiyaç vardir. 


\section{Kaynaklar}

1. Fontaine I, Guérard des Lauriers A. Three cases of matricide. Ann Med Psychol. 1994;152(8):497-510.

2. Myers WC, Kemph JP. Characteristics and treatment of four homicidal adolescents. J Am Acad Child Adolesc Psychiatry. 1988; 27(5):595-9.

3. Sellers BG, Heide KM. Male and female child murderers: an empirical analysis of U.S. arrest data. Int J Offender Ther Comp Criminol. 2012; 56(5):691-714.

4. Holcomb WR. Matricide: primal aggression in search of selfaffirmation. Psychiatry. 2000;63(3):264-87.

5. Heide KM, Frei A. Matricide: a critique of the literature. Trauma Violence Abuse. 2010;11(1):3-17.

6. Malmquist CP. Adolescent parricide as a clinical and legal problem. J Am Acad Psychiatry Law. 2010;38(1):73-9.

7. Heide KM, Roe-Sepowitz D, Solomon EP, Chan HC. Male and female juveniles arrested for murder: a comprehensive analysis of U.S. data by offender gender. Int J Offender Ther Comp Criminol. 2012;56(3):356-84.

8. Lewis DO, Lovely R, Yeager C. Intrincis and environmental characteristics of juvenile murders. J Am Acad Child Adolesc Psychiatry 1988;27:582-587.
9. Ogunwale A, Abayomi O. Matricide and schizophrenia in the 21(st) century: a review and illustrative cases. Afr J Psychiatry. 2012; 15(1):55-7.

10. Heide KM, Boots DP. A comparative analysis of media reports of US parricide cases with officially reported national crime data and the psychiatric and psychological literature. Int J Offender Ther Comp Criminol. 2007; 51(6):646-75.

11. Wick R, Mitchell E, Gilbert, JD, Byard RW. Matricides in South Australia-a 20-year retrospective review. J Forensic Leg Med. 2008; 15(3):168-71.

12. Dunjić B, Marić N, Jasović-Gasić M, Dunjić D. Parricide: psychiatric morbidity. Srp Arh Celok Lek. 2008; 136(11-12):635-9.

13. Sayhan MB, Söğüt Ö, Gökdemir MT, Kara PH, Bircan M. Öldürme ardından özkıyım: Olgu sunumu ve literatürün gözden geçirilmesi. Anadolu Psikiyatri Derg 2011; 12:312-314.

14. Dantas S, Santos A, Dias I, Dinis-Oliveira RJ, Magalhães T. Parricide: a forensic approach. J Forensic Leg Med. 2014; 22:1-6.

15. Woodworth M, Agar AD, Coupland RB. Characteristics of Canadian youth-perpetrated homicides. Criminal justice and behavior, 2013;40(9), 1009-1026.

16. Breslow RE, Klinger BI, Erickson BJ: The disruptive behavior disorders in the psychiatric emergency service. General Hospital Psychiatry 1999;21:214-219. 